\title{
PRAWNOMIĘDZYNARODOWE UWARUNKOWANIA SAMORZĄDU TERYTORIALNEGO
}

\section{WPROWADZENIE}

Organizacja i funkcjonowanie (działalność) władzy publicznej w demokratycznym państwie prawnym należą do materii, która jest przedmiotem zainteresowania prawoznawstwa. Nauki prawne, jak wiadomo, nie wyczerpują domeny poznania naukowego odnoszącego się do budowy i działalności aparatu państwowego (publicznego) we współczesnych warunkach polityczno-społeczno-gospodarczych. Wzmiankowane zagadnienia sa roztrzasane z niejednolitych punktów widzenia na gruncie różnych obszarów wiedzy, gdzie w obrębie wydzielanych dziedzin nauki oraz dyscyplin naukowych dociekane sa kwestie zajmujące badaczy i mające nierzadko bezpośrednie znaczenie dla człowieka żyjącego w określonych społecznościach (wspólnotach) w państwie ${ }^{1}$.

Powstawanie i działalność właściwych wspólnot immanentnie wiążą się z kategorią interesu lokalnego, która - jak podkreśla Michał Kulesza - ma charakter obiektywny, co znaczy, że interesy te (potrzeby) występują realnie, niezależnie od tego, czy akceptuje to nauka prawa i czy uwzględnia je prawo pozytywne, czy więc istnieją konstrukcje prawne umożliwiające prawidłowa reprezentację i artykulację, a wreszcie - realizację zbiorowych potrzeb miejscowej ludności. Problem nie dotyczy więc kwestii, jak trafnie podkreśla autor, czy owe interesy i potrzeby istnieja, lecz wyłącznie tego, czy i w jaki sposób kwestia ta rozwiązana jest $\mathrm{w}$ sferze porządku prawnego, tzn. czy uznaje się odrębność celów lokalnych, w zakresie prawnie zdefiniowanym, wyrażających interesy społeczności terytorialnych od celów ogólnopaństwowych, stanowiacych wyraz potrzeb ogólnospołecznych w ścisłym znaczeniu tego słowa ${ }^{2}$. Dalej Kulesza uwypukla, że zaakceptowanie poglądu o odrębności celów (interesów) lokalnych od celów ogólnopaństwowych i o konieczności uwzględnienia swoistości tych kategorii w obrocie prawnym i w systemie zarządzania publicznego jest równoznaczne z podmiotowym widzeniem jednostki terytorialnej (społeczności terytorialnej, władzy terytorialnej, wspólnoty samorządowej). Wtedy bo-

${ }^{1}$ Por. F. Longchamps, Założenia nauki administracji, Wrocław 1949; idem, Wspótczesne kierunki $w$ nauce prawa administracyjnego na zachodzie Europy, Warszawa 1968; idem, Z problemów poznania prawa, Wrocław 1968.

${ }^{2}$ M. Kulesza, Niektóre zagadnienia prawne definicji samorzadu terytorialnego, „Państwo i Prawo" 45, 1990, z. 1, s. 23. 
wiem podmiotem zarządzania publicznego nie jest tylko „władza państwowa” jako całość i jej - tej władzy - ogniwa różnego szczebla i rodzaju, realizujące tę samą zasadniczą linię polityki państwa, lecz, co uwypuklamy za autorem, w szczególności gmina i jej organy reprezentujące interesy określonej, danej społeczności lokalnej, działające wprost na rzecz zaspokojenia zbiorowych potrzeb tej społeczności, i - równolegle - organy państwa reprezentujące interes ogólnospołeczny i kreujące w związku z tym określoną politykę ogólnopaństwowa. Nie jest to sprzeczne, jak zaznacza Kulesza, z jednoczesnym ujmowaniem układów lokalnych jako subsystemów układu ogólnopaństwowego, w ramach których następuje realizacja pewnych celów o charakterze ogólnopaństwowym. Autor przyjmuje, że w zależności od przyjętych tu mechanizmów prawnych realizowanie tych ogólnopaństwowych celów dochodzi do skutku na zasadzie bądź decentralizacji, bądź dekoncentracji władztwa publicznego ${ }^{3}$.

Według Mariana Zimmermanna decentralizacja i centralizacja to rozróżnienie przeprowadzone z punktu widzenia stosunku organu wyższego do organu niższego. Dodać należy, jak akcentuje autor, że badając organy administracyjne, możemy wyszukiwać inne kryteria będące podstawą rozróżnień, np. powstanie organu (wybór czy mianowanie), stosunek osobisty urzędników (płatny czy też nie) itp. Jest tutaj możliwe jeszcze inne kryterium: Jakiego podmiotu jest dana władza organem? Władza może być organem państwa, jednak istnieją władze, które są organami innych podmiotów, np. organy gminne. Sprawują one władzę nie w imieniu państwa, lecz w imieniu gminy jako odrębnego podmiotu. Systemy decentralizacji, jak zaznacza Zimmermann, moga być różne: administracja zdecentralizowana może być wykonywana w imieniu państwa, bądź też w imieniu innych podmiotów prawa publicznego ${ }^{4}$.

Przy podziale administracyjnym państwa należy dążyć - jak podkreślono podczas Pierwszego Polskiego Kongresu Nauk Administracyjnych (Poznań, 20-23 czerwca 1929 r.) - do tworzenia takich jednostek administracyjnych, które by były regionami wyodrębniającymi się pod względem warunków i potrzeb miejscowych, stawiającymi administracji publicznej jasne i określone zadania. Uwypuklano też, że tylko administracja lokalna może ożywić i należycie - jak wyrażono - wyzyskać dla dobra państwa wszelkie siły społeczne i materialne kraju. W związku z powyższym Pierwszy Polski Kongres Nauk Administracyjnych wskazywał na potrzebę dostosowania środków finansowych samorządu terytorialnego do jego zakresu działania jako jedną z najpilniejszych potrzeb administracji publicznej ${ }^{5}$.

Powyższe wypowiedzi dotyczące samorządu terytorialnego wkomponowuja się w ustalenia poczynione przez Tadeusza Bigo, który stwierdza: jeśli doskonała demokracja oznacza zespolenie (identyfikację) jednostki ze zbiorowościa,

${ }^{3}$ M. Kulesza, op. cit., s. 24. Por. K. Kokocińska, Prawny mechanizm prowadzenia polityki rozwoju w zdecentralizowanych strukturach władzy publicznej, Poznań 2014.

${ }^{4}$ M. Zimmermann, Nauka administracji i polskie prawo administracyjne, cz. 1, Poznań 1949, s. 62 .

${ }^{5}$ Z I-go Polskiego Kongresu Nauk Administracyjnych w Poznaniu (20-23 czerwca 1929), „Ruch Prawniczy, Ekonomiczny i Socjologiczny” 9, 1929, s. 1224. Por. Pierwszy Polski Kongres Nauk Administracyjnych w Poznaniu. Zeszyt II. Referaty zgtoszone na Kongres, Warszawa 1929, s. 5-560. 
to samorząd terytorialny może być pośrednim etapem tego procesu, jego ogniwem. Tylko wtedy - jak pisze dalej autor - gdy pojmuje się omawiany samorząd jako narzędzie walki z rządem centralnym, dochodzi się do konkluzji, że oznacza on rozbicie jedności państwa demokratycznego. Jeśli natomiast widzi się $\mathrm{w}$ samorządzie terytorialnym formę decentralizacji, to raczej popiera on proces zespolenia jednostki z państwem ${ }^{6}$.

Kluczowe normy prawne dla kształtowania statusu jurydycznego (pozycji prawnej, zadań, kompetencji, funkcji itd.) samorządu terytorialnego w strukturze organizacyjnej państwa zawiera Konstytucja Rzeczypospolitej Polskiej. Ustawa zasadnicza stanowi, że ustrój terytorialny Rzeczypospolitej Polskiej zapewnia decentralizację władzy publicznej. Zasadniczy podział terytorialny państwa uwzględniajacy więzi społeczne, gospodarcze lub kulturowe i zapewniający jednostkom terytorialnym zdolność wykonywania zadań publicznych określa ustawa. Ogół mieszkańców jednostek zasadniczego podziału terytorialnego - jak przyjmuje ustrojodawca - stanowi z mocy prawa wspólnotę samorządowa. Samorząd terytorialny uczestniczy w sprawowaniu władzy publicznej. Przysługująca mu w ramach ustaw istotną część zadań publicznych samorząd wykonuje w imieniu własnym i na własną odpowiedzialność. Samorząd terytorialny wykonuje zadania publiczne niezastrzeżone przez Konstytucję lub ustawy dla organów innych władz publicznych ${ }^{7}$.

Stanowisko Unii Europejskiej wobec samorządu terytorialnego jest odmienne od przywoływanej treści przepisów Konstytucji RP. Unia Europejska - w świetle Traktatu o Unii Europejskiej - szanuje równość państw członkowskich wobec Traktatów, jak również ich tożsamość narodowa, nierozerwalnie związana z ich podstawowymi strukturami politycznymi i konstytucyjnymi, $\mathrm{w}$ tym - co akcentujemy - w odniesieniu do samorządu regionalnego i lokalnego. Szanuje podstawowe funkcje państwa, zwłaszcza funkcje mające na celu zapewnienie jego integralności terytorialnej, utrzymanie porządku publicznego oraz ochronę bezpieczeństwa narodowego. W szczególności bezpieczeństwo narodowe pozostaje w zakresie wyłącznej odpowiedzialności każdego państwa członkowskiego $^{8}$.

$\mathrm{Na}$ tle tak wybiórczo zarysowanych zagadnień odnoszących się do samorządu terytorialnego wskażmy, iż celem niniejszego opracowania jest przegląd i zbadanie zawartości niektórych wypowiedzi doktryny podejmującej tematykę prawnomiędzynarodowych uwarunkowań samorządu terytorialnego. Akcentowany zamiar nawiązuje m.in. do stanowiska ustrojodawcy wyrażonego

${ }^{6}$ T. Bigo, Zwiqzki publiczno-prawne w świetle ustawodawstwa polskiego, Warszawa 1928, s. $218-219$.

${ }^{7}$ Art. 15, 16 i 163 Konstytucji Rzeczypospolitej Polskiej z 2 kwietnia 1997 r., Dz. U. Nr 78, poz. 483, sprost. Dz. U. 2001, Nr 28, poz. 319 ze zm. (dalej jako: Konstytucja RP, Konstytucja). Por. J. Stępień, Trybunat Konstytucyjny wobec samorzqdu terytorialnego, w: F. Rymarz, A. Jankiewicz (red.), Trybunat Konstytucyjny. Księga XV-Lecia, Warszawa 2001, s. 176; J. Boć, Konstytucja a prawo administracyjne, „Ruch Prawniczy, Ekonomiczny i Socjologiczny” 73, 2011, z. 2, s. 70 .

${ }^{8}$ Art. 4 ust. 4 Traktatu o Unii Europejskiej (wersja skonsolidowana Dz. Urz. C 326 z 26 października 2012 r., s. 13-46; dalej jako: TUE). Por. B. Dolnicki, Modele samorzqdu terytorialnego w Europie $i$ w Polsce, Katowice 1994. 
w art. 9 Konstytucji: Rzeczpospolita Polska przestrzega wiążącego ją prawa międzynarodowego. Zrealizowanie założonego celu artykułu może stanowić odniesienie do rozwijania prowadzonych dotąd badań w kierunku ustalenia znaczenia prawa międzynarodowego dla statusu prawnego samorządu terytorialnego w Polsce.

\section{PRZEGLĄD WYPOWIEDZI PIŚMIENNICTWA}

Tematyka ujęta $\mathrm{w}$ tytule opracowania jest podejmowana w różnych obszarach zagadnień wiążących się z pozycją prawną i działalnością samorządu terytorialnego. Znaczenie prawa międzynarodowego dla samorządu terytorialnego należy, naszym zdaniem, wiązać ze zjawiskiem europeizacji administracji publicznej i prawa administracyjnego.

Badając przemiany w obrębie władzy wykonawczej, Karol Sobczak wskazuje, że piąta tendencja rozwojowa administracji publicznej wiąże się z przyjmowaniem w niej pewnych standardów o charakterze międzynarodowym ${ }^{9}$. Piotr Buczkowski, na co wskazuje Teresa Rabska, był inicjatorem i pomysłodawca tematu badawczego „Administracja publiczna w świetle integracji z UE”, był prekursorem krzewienia idei europejskich. Przywiązywał on ogromna wagę do spraw administracyjnych, a szczególnie do ustroju samorządu terytorialnego, którego był autentycznym współtwórca, oraz do sposobu działania administracji publicznej ${ }^{10}$.

Po okresie transformacji ustrojowej, o czym pisze Zofia Duniewska, w wyniku procesów integracyjnych (szczególnie członkostwa w Unii Europejskiej, choć oczywiście z innych przyczyn i przy aprobacie państwa polskiego), kształt obowiązującego w Polsce prawa administracyjnego nakreślony został w dużej mierze unormowaniami międzynarodowymi i regionalnymi, zwłaszcza unijnymi ${ }^{11}$.

W obszarze oddziaływania procesów globalizacji na pozycję i funkcje administracji publicznej we współczesnym świecie Zygmunt Niewiadomski wskazuje procesy umiędzynarodowienia administracji publicznej ${ }^{12}$. Procesy umiędzynarodowienia administracji publicznej związane są z integracją w ramach

${ }^{9}$ K. Sobczak, Administracja publiczna. Problemy węzłowe, Warszawa 1993, s. 40.

${ }_{10}$ T. Rabska, Administracja publiczna $w$ świetle integracji $z$ Unia Europejska, „Samorząd Terytorialny" 13, 2003, nr 3, s. 3. Por. P. Buczkowski, Samorzad lokalny i budowa społeczeństwa obywatelskiego w Polsce do 1990 r., w: idem (red.), Odrodzenie samorzadu terytorialnego. Budowa społeczeństwa obywatelskiego, Poznań 1994, s. 9; idem, Krajowy Sejmik Samorzqdu Terytorialnego. Geneza. Organizacja. Działalność w I kadencji, w: idem (red.), Samorzqd zorganizowany, Poznań 1994, s. 9; P. Buczkowski, K. Bondyra, P. Śliwa (red.), Jaka Europa? Regionalizacja a integracja, Poznań 1998.

${ }_{11}$ Z. Duniewska, W kwestii czynników kształtujacych prawo administracyjne, w: J. Supernat (red.), Między tradycja a przyszłościa w nauce prawa administracyjnego. Księga jubileuszowa dedykowana Profesorowi Janowi Bociowi, Wrocław 2009, s. 121.

${ }^{12}$ Z. Niewiadomski, Pojęcie administracji publicznej, w: System prawa administracyjnego, red. R. Hauser, Z. Niewiadomski, A. Wróbel, t. 1: Instytucje prawa administracyjnego, Warszawa 2010, s. 32. 
Unii Europejskiej (Wspólnot Europejskich), ale także wzrostem roli i znaczenia współpracy międzynarodowej i przejmowaniem niektórych funkcji administracji publicznej poszczególnych państw przez organizacje międzynarodowe ${ }^{13}$.

Pojęcie europeizacji, jak wynika z poczynionych w doktrynie ustaleń, jest używane w różnym znaczeniu ${ }^{14}$. Można je bowiem traktować bardzo szeroko jako poszukiwanie pewnego uniwersalnego systemu wartości charakterystycznych dla danego kręgu kulturowego, a mianowicie kultur europejskich. Podejście takie, aczkolwiek interesujace, przenosiłoby jednak zakres naszych rozważań bardziej na zagadnienia filozofii prawa niż nauk dogmatycznych. $\mathrm{Z}$ drugiej strony w opinii Małgorzaty Jaśkowskiej pojęcie europeizacji prawa administracyjnego może być traktowane wasko: jako kwestia aktualnych i przyszłych zobowiązań międzynarodowych Polski związanych z udziałem w UE. Europeizacja tego prawa wiąże się nie tylko z prawem europejskim jako prawem Unii Europejskiej, ale w szerokim stopniu jest konsekwencja udziału Polski w Radzie Europy. Wydziela się trzy obszary europeizacji prawa: recepcję prawa, wpływ międzynarodowych organizacji i ich aktów, które mają znaczenie dla narodowych porządków prawnych, w tym w szczególności udział w Radzie Europy oraz wpływ prawa unijnego ${ }^{15}$.

Tym samym umowną kwestia jest, jak pojmować pojęcie „europeizacja polskiego prawa administracyjnego" - owa „europeizacja” może bowiem być, zdaniem Zbigniewa Leońskiego, rozumiana niejednolicie. Po pierwsze, chodzić tu może o przenoszenie na nasz grunt instytucji prawnych, które wykształciły się w Europie Zachodniej. W gruncie rzeczy byłby to powrót do tradycji z okresu międzywojnia, kiedy to polska myśl prawnicza oraz ustawodawstwo sięgały do tradycji kulturowych wykształconych na zachodzie Europy, modyfikowanych jednak z upływem czasu. Po wtóre, w opinii Leońskiego określenie „europeizacja" można by rezerwować tylko do takich procesów kształtowania instytucji polskiego prawa administracyjnego, które są charakterystyczne dla Unii Europejskiej. Takie pojmowanie „europeizacji” nie pokrywa się w pełni z pierwszym pojęciem, gdyż obejmuje tylko instytucje wykształcone na potrzeby funkcjonowania określonej struktury ponadpaństwowej - Unii Europejskiej oraz prawa unijnego. Być może, pisze dalej Leoński, inne pojmowanie „europeizacji” polskiego prawa administracyjnego jest także tu uzasadnione. Cele badawcze nie moga w tym zakresie stawiać barier poznawczych. Można zatem powiedzieć, że każde z zaproponowanych ujęć jest uprawnione i możliwe w ramach badań naukowych reprezentantów nauki prawa administracyjnego ${ }^{16}$.

Zaznaczmy też, że w opinii Ireny Lipowicz europeizacja administracji publicznej może być także rozpatrywana jako część erozji suwerenności państwa, ponieważ to ono traci część władztwa nad własnymi organami publicznymi - krajową władzą wykonawcza. Administracja publiczna swoje normy i swój

\footnotetext{
13 Ibidem.

${ }_{14}$ M. Jaśkowska, Europeizacja prawa administracyjnego, „Państwo i Prawo” 54, 1999, z. 11, s. 18 .

15 Ibidem.

16 Z. Leoński, Wprowadzenie, w: Z. Janku et al. (red.), Europeizacja polskiego prawa administracyjnego, Wrocław 2005, s. 13-14.
} 
punkt odniesienia znajduje bowiem już gdzie indziej - w szerszej płaszczyźnie europejskiej. Jak stwierdza Lipowicz, ratyfikowane konwencje, jak Europejska karta samorządu lokalnego (EKSL, Karta) czy Konwencja nr 108 w sprawie ochrony danych osobowych, sa w mniejszości wobec licznych standardów typu soft law wywierających wpływ głównie na kandydatów do UE. Proces ten nasila się w samej administracji unijnej. Autorka jednak stawia trafne pytanie: Czy „sieciowa” administracja publiczna, którą obecnie jesteśmy tak zafascynowani, nie spowoduje w skali europejskiej zatarcia odpowiedzialności za podejmowanie decyzji przez administrację publiczną. ${ }^{17}$

W kontekście roli prawa międzynarodowego dla samorządu terytorialnego uwypuklane jest w obiegu naukowym szczególnie istotne znaczenie różnej natury prawnej aktów („dokumentów”) i praktyki Rady Europy ${ }^{18}$. Jest odczuwalne, zdaniem Stanisława Biernata, znaczenie prawa tworzonego w ramach Rady Europy zarówno dla prawa organizacyjnego (ustrojowego) administracji publicznej, materialnego prawa administracyjnego, jak i postępowania administracyjnego oraz sądowej kontroli administracji państw należących do Rady Europy i będaccych stronami Konwencji, w tym Polski ${ }^{19}$.

Trzeba jednak pamiętać, o czym wspomina Hubert Izdebski ${ }^{20}$, że to Rada Europy pierwsza wprowadziła „europejska” terminologię i symbole, jak też wybrała Strasburg na swoją siedzibę. „Mniejsza” Europa, w postaci Unii i jej instytucjonalnych poprzedniczek, przejęła to wszystko od Rady Europy, oczywiście za jej zgodą. Jedynym aspektem działalności Rady Europy, który w opinii autora wydaje się stosunkowo dobrze znany w Polsce, czasem może lepiej niż w wielu „starych” państwach członkowskich, jest funkcjonowanie w jej ramach instytucji ochrony praw człowieka w postaci Europejskiej Komisji Praw Człowieka i - zwłaszcza - Europejskiego Trybunału Praw Człowieka. Polska, pisze dalej Izdebski, stając się członkiem Rady Europy, od razu uznała prawo swoich obywateli do składania indywidualnej skargi do Europejskiej Komisji Praw Człowieka i obowiązkową jurysdykcję Trybunału²1.

${ }^{17}$ I. Lipowicz, Europeizacja administracji publicznej, „Ruch Prawniczy, Ekonomiczny i Socjologiczny" 70, 2008, z. 1, s. 8-9.

18 Por. L. Kieres, Analiza zgodności polskiego prawa samorzadu terytorialnego z Europejska Karta Samorzqdu Terytorialnego, „Samorząd Terytorialny” 8, 1998, nr 9; J. Jaskiernia, Zgromadzenie Parlamentarne Rady Europy, Warszawa 2000; idem, Rada Europy a problemy mediów masowych, Warszawa 2002; J. Kaczmarek, Rada Europy, Wrocław 2002; H. Machińska (red.), Polska i Rada Europy: 1990-2005, Warszawa 2005; F. Benoit-Rohmer, H. Klebes, Prawo Rady Europy. W stronę ogólnoeuropejskiej przestrzeni prawnej, przeł. M. A. Nowicki, Warszawa 2006; T. Szewc, Dostosowanie prawa polskiego do zasad Europejskiej Karty Samorzadu Terytorialnego, Bydgoszcz 2006; H. Machińska (red.), 60 lat Rady Europy. Tworzenie i stosowanie standardów prawnych, Warszawa 2009.

19 S. Biernat, Europejskie prawo administracyjne i europeizacja krajowego prawa administracyjnego (zarys problematyki), „Studia Prawno-Europejskie” 6, 2002, s. 71. Por. Wspótczesne europejskie problemy prawa administracyjnego $i$ administracji publicznej. W 35. rocznice utworzenia Instytutu Nauk Administracyjnych Uniwersytetu Wrocławskiego, Wrocław 2005.

${ }^{20}$ H. Izdebski, Rada Europy. Organizacja demokratycznych państw Europy i jej znaczenie dla Polski, Warszawa 1996, s. 6.

21 Ibidem. 
Wpływ standardów prawnomiędzynardowych na zdecentralizowana formę administracji publicznej - samorząd terytorialny - analizował niejednokrotnie Bogdan Dolnicki ${ }^{22}$. Źródłem regulacji prawnych dotyczących ustroju samorządu lokalnego jest zdaniem autora Europejska karta samorządu terytorialnego, która już od 1994 r. jako ratyfikowana umowa międzynarodowa wiąże Polskę. Od momentu ratyfikacji EKSL obowiązuje w Polsce i wywiera bezpośredni wpływ na krajowe ustawodawstwo samorządowe ${ }^{23}$.

W preambule EKSL Rada Europy, jak zaznacza Janusz Sługocki, określono ideowe przesłanki roli samorządu terytorialnego w życiu publicznym państw europejskich. Szczególnie zaakcentowany został związek między samorządem a demokracją. Społeczności lokalne uznano w zapatrywaniu autora za jeden z zasadniczych filarów ustroju demokratycznego, którego kluczowym elementem jest prawo obywateli do uczestniczenia w zarządzaniu sprawami publicznymi. Co więcej, ze względu na możliwość realizowania tego prawa w najbardziej bezpośredni sposób samorząd terytorialny ma wyjątkowo istotne znaczenie dla funkcjonowania całego systemu demokratycznych struktur w państwie. Zdaniem Sługockiego ochrona i ugruntowanie samorządu terytorialnego w poszczególnych krajach Europy przyczyniają się w znacznym stopniu do budowy Europy na podstawie zasad demokracji i decentralizacji władzy publicznejej.

Europejska karta samorządu terytorialnego w art. 2 nakłada na państwo obowiązek uznania, na co wskazuje Leon Kieres, zasady samorządności terytorialnej w prawie wewnętrznym (,musi być uznana”): w Konstytucji (w miarę możliwości) oraz w innych aktach prawa wewnętrznego. Praktyka interpretacyjna Karty, kształtowana przez stanowisko oficjalne instytucji Rady Europy powołanych do analizy stopnia uwzględniania (przestrzegania) jej postanowień przez członków Rady, wskazuje na szczególne znaczenie ${ }^{25}$ konstytucyjnego ujęcia zasady samorządności terytorialnej w prawie wewnętrznym. Tym samym Konstytucja traktowana jest jako podstawowe źródło informacji o poszanowaniu zasady samorządności terytorialnej oraz miejscu jednostek samorządowych w ustroju państwa ${ }^{26}$.

${ }^{22}$ B. Dolnicki, Czy polskie ustawodawstwo samorzadowe odpowiada standardom europejskim?, „Samorząd Terytorialny” 4, 1994, nr 9, s. 11; idem, Modele samorzqdu terytorialnego...; idem, Ustrój samorzadu terytorialnego w świetle standardów europejskich, w: Z. Janku et al. (red.), op. cit., s. 139. Por. K. Chorąży, Zagadnienia ustroju lokalnego Francji, Lublin 1998, s. 52; I. Skrzydło-Niżnik, Model ustroju samorzqdu terytorialnego w Polsce na tle zagadnień ustrojowego prawa administracyjnego, Kraków 2007; P. Lisowski, Relacje strukturalne w polskim samorzadzie terytorialnym, Wrocław 2013.

${ }^{23}$ B. Dolnicki, Ustrój samorzqdu terytorialnego..., s. 140. Por. M. Kulesza, K. Galus, M. Tułowiecki, Harmonizacja prawa polskiego w zakresie przepisów dotyczacych samorzadu terytorialnego, Warszawa 2001; J. Stępień, Samorzqd terytorialny w konstytucyjnym ustroju państwa, w: M. Zubik (red.), Księga XX-lecia orzecznictwa Trybunału Konstytucyjnego, Warszawa 2006, s. 615.

${ }^{24}$ J. Sługocki, Zasada subsydiarności $w$ poziomej teorii i $w$ praktyce, w: B. Filipiak, A. Szewczuk (red.), Samorzad terytorialny w zintegrowanej Europie, t. 2, Szczecin 2006, s. 195.

${ }^{25}$ L. Kieres, op. cit., s. 4.

26 Ibidem, s. 5. 
Polskie reformy w zakresie odbudowy samorządu terytorialnego budziły, jak pisze Jerzy Regulski ${ }^{27}$, ogromne zainteresowanie za granica. Wiele rządów i organizacji pozarządowych zgłaszało gotowość pomocy w tym obszarze. Z natury rzeczy oferty te były kierowane do Pełnomocnika Rządu do spraw Reformy Samorządu Terytorialnego jako jedynego organu związanego z reforma samorządowa. Bez wspomnianej pomocy rozwój demokracji lokalnej w Polsce przebiegałby znacznie wolniej. Reforma samorządowa, podobnie zreszta jak reformy gospodarcze, znacznie wyżej była notowana na Zachodzie niż w Polsce. Należy też zdaniem autora podkreślić ogromna pomoc merytoryczną, jaką udzieliła wówczas Polsce Rada Europy. Europejska karta samorządu terytorialnego, opracowana w ramach Rady Europy na podstawie doświadczeń krajów demokratycznych, była wzorem, do którego nawiązywano w zakresie omawianych przemian w Polsce. Michał Kulesza i Jerzy Stępień przedstawili w Strasburgu projekty polskich ustaw samorządowych, zyskując wielkie uznanie i potwierdzenie dla ich pełnej zgodności ze standardami europejskimi. Rada Europy wspierała nas cały czas zespołami ekspertów, którzy odegrali istotną rolę w fazie przygotowania omawianych reform ${ }^{28}$.

Adam Chełmoński - na gruncie oddziaływania EKSL w relacji do ustroju i funkcjonowania polskiej administracji publicznej - pisze, że w płaszczyźnie stosowania prawa postanowienia EKSL winny być ważną wskazówką w interpretacji ustawodawstwa polskiego. Dotyczy to przede wszystkim relacji między administracją rządową a wspólnotami lokalnymi (samorząd terytorialny). Zdarzało się często, w opinii autora, że w tych relacjach prawo interpretowane było na korzyść administracji rządowej. Zarówno gdy chodzi o zakres kompetencji, jak i o sposób ich wykonywania. Takie rozumowanie było w pewnej mierze reliktem - według Chełmońskiego - niedawnej przeszłości, gdy organy o szerszej kompetencji terytorialnej były organami hierarchicznie wyższymi, a racje polityki centralnej miały priorytet wobec racji lokalnych. Autor zasadnie zakładał, że wprowadzenie EKSL do polskiego ustawodawstwa przełamie ten schemat i da władzom lokalnym skuteczny instrument interpretacyjny dla ochrony praw i interesów społeczności lokalnych. Chełmoński uwypuklał, że dotyczy to również - może nawet w większym stopniu - orzecznictwa Trybunału Konstytucyjnego, Naczelnego Sądu Administracyjnego i sądów powszechnych. Karta stanowić może w zapatrywaniu autora ważne oparcie dla sądowej interpretacji prawa, zarówno w rozstrzygnięciach indywidualnych, jak i w ocenie aktów generalnych stanowiących podstawę działania administracji publiczneje.

${ }_{27}$ J. Regulski, Samorzad III Rzeczypospolitej. Koncepcje i realizacja, Warszawa 2000, s. 88. Por. T. Rabska, Samorzqd terytorialny $w$ strukturze aparatu państwa (perspektywy przebudowy administracji lokalnej), „Ruch Prawniczy, Ekonomiczny i Socjologiczny” 55, 1993, z. 3, s. 23.

${ }^{28}$ J. Regulski, op. cit., Warszawa 2000, s. 88-89. Por. L. Kieres, Prawo europejskie wobec samorzadu terytorialnego, w: R. P. Krawczyk, M. Stec (red.), Samorzad-finanse-nadzór i kontrola. XX-lecie Regionalnych Izb Obrachunkowych, Warszawa 2013, s. 20.

${ }^{29}$ A. Chełmoński, Polski samorzad terytorialny na tle Europejskiej Karty Samorzadu Terytorialnego, w: P. Buczkowski (red.), Odrodzenie samorzqdu terytorialnego. Budowa społeczeństwa obywatelskiego, Poznań 1994, s. 120. Por. M. Stahl, Dorobek orzeczniczy sqdów administracyj- 
Nauka prawa administracyjnego z żywym zainteresowaniem analizowała zagadnienia wiążące się z udziałem naszego państwa w Radzie Europy. Wejście Polski do Rady Europy, podkreśla Janusz Łętowski, powitane zostało u nas z powszechnym aplauzem, uznano to zreszta za oczywiste, jak bowiem często powtarzano w różnych wypowiedziach - w Europie byliśmy od zawsze, a jedynie narzucony z zewnątrz ustrój totalitarny uniemożliwiał nam nie tylko pełne potwierdzenie owej okoliczności, lecz także korzystanie z dobrodziejstw, jakie miałaby dawać automatycznie owa przynależnośćc ${ }^{30}$.

Treść EKSL - co już wzmiankowano - nie była bez znaczenia dla kształtowania cytowanych wyżej przepisów Konstytucji dotyczących samorządu terytorialnego. Bogusław Banaszak w kontekście konstrukcji decentralizacji odnoszonej do pozycji samorządu terytorialnego w strukturze państwa akcentuje europejskie podstawy zasady pomocniczości ${ }^{31}$. Jego zdaniem najlepiej zasadę pomocniczości definiuje art. 4 ust. 3 EKSL: „Generalnie odpowiedzialność za sprawy publiczne powinny ponosić przede wszystkim te organy władzy, które znajdują się najbliżej obywateli. Powierzając te funkcje innemu organowi władzy, należy uwzględnić zakres i charakter zadania oraz wymogi efektywności i gospodarności”. Wiąże się z tym z reguły domniemanie kompetencji na rzecz samorządu terytorialnego, a zwłaszcza gminy ${ }^{32}$.

Analiza wybranych konstytucji kontynentalnych państw europejskich - przeprowadzona przez Jerzego Korczaka - pokazuje, że nie istnieje żaden standard jurydyczny samorządu terytorialnego na poziomie ustrojowym (konstytucyjnym). Problem funkcjonowania samorządu terytorialnego w państwie, tak przecież istotny dla ustrojów państw demokratycznych, w opinii autora, może być rozwiązany zarówno bardzo szczegółowo, jak i bardzo pobieżnie, moga to być regulacje dotykające rzeczy iście fundamentalnych istota samorządu, miejsce w ustroju organów władzy publicznej i wzajemne relacje między nimi, gwarancje samodzielności jednostek samorządu - ale też niemające dla samego istnienia samorządu terytorialnego i jego jednostek znaczenia gwarancje praw grup etnicznych ${ }^{33}$. Przeprowadzone badania podkreślają również, że w nauce administracji zasadę pomocniczości powiązano z problematyką samorządu terytorialnego w następstwie przyjęcia, iż wpisanie jej do zasad ustrojowych państwa oznacza założenie, że obok państwa jako najwyższej wspólnoty istnieje wiele wspólnot pomniejszych, a wśród nich wspólnoty samorządowe. Zaczęto rozpatrywać relację wertykalną mię-

nych w sprawach samorzadowych, „Zeszyty Naukowe Sądownictwa Administracyjnego” 2010, nr 5-6, s. 402.

${ }^{30}$ J. Łętowski, Rada Europy o postępowaniu administracyjnym, „Annales Universitatis Mariae Curie-Skłodowska. Sectio G. Ius" 40, 1993, s. 93. Por. J. Zimmermann, Aksjomaty prawa administracyjnego, Warszawa 2013.

${ }^{31}$ B. Banaszak, op. cit., w: J. Korczak (red.), 20 lat samorzqdu terytorialnego $w$ II $i$ III Rzeczypospolitej, Wrocław 2010, s. 74. Por. J. Starościak, Decentralizacja administracji, Warszawa 1960.

${ }^{32}$ B. Banaszak, Stowo wstepne nt. samorzqdu..., s. 75.

${ }^{33}$ J. Korczak, Konstytucyjne podstawy struktury $i$ funkcji samorzqdu terytorialnego, w: R. Hauser, Z. Niewiadomski, A. Wróbel (red.), Konstytucyjne podstawy funkcjonowania administracji publicznej, t. 2, Warszawa 2012, s. 176. Por. B. Dolnicki, Modele samorzadu terytorialnego. 
dzy państwem a utworzonymi z jego woli i w jego ramach jednostkami terytorialnymi i działajacymi na jego obszarze organizacjami pozarządowymi ${ }^{34}$. Sytuacja stała się jeszcze bardziej złożona - w opinii Korczaka - gdy zaczęła powstawać Unia Europejska i zmierzać ku coraz większej integracji, realizując hasło „Europa regionów”, wówczas bowiem obok państwa pojawiła się wspólnota europejska, wspólnota ponadpaństwowa i zasadę subsydiarności zaczęto odnosić teraz do relacji Unia Europejska - państwo członkowskie struktury wewnątrzpaństwowe w zależności od ich wieloszczeblowości, czego szczególnym przejawem stały się postanowienia traktatu z Maastricht. Oto w art. 3b czytamy o tym, że Wspólnota działa wyłącznie w granicach jej przydzielonych, a w dziedzinach pozostałych podejmuje działania zgodnie z zasadą subsydiarności, gdy cele nie mogłyby być osiagnięte przez państwo członkowskie, przy czym jednak środki użyte nie mogą wykraczać poza owe cele. Dla lepszego zrozumienia i stosowania tego przepisu traktat amsterdamski dodał Protokół w sprawie stosowania zasady pomocniczości i proporcjonalności, po traktacie z Lizbony zaś nie tylko zmieniono numerację tego przepisu, lecz także zwrócono uwagę na możliwość bezpośredniego osiagania celów zarówno na poziomie państwa członkowskiego (centralnym), jak i na poziomie regionalnym i lokalnym. Toteż w opinii autora proces narastającej integracji Unii Europejskiej doprowadza do nadania zasadzie subsydiarności w warunkach równoległego funkcjonowania prawa krajowego i prawa europejskiego swoistych cech interpretacyjnych ${ }^{35}$.

Zaznaczmy również na gruncie prowadzonych rozważań, że przywrócenie w Polsce samorządu terytorialnego od początku - zdaniem Jana Jeżewskiego - zwróciło uwagę na instytucje samorządowe w państwach Europy Zachodniej. Długa tradycja samorządu zachodnioeuropejskiego, jego doświadczenia praktyczne, a przede wszystkim konstrukcja prawna podstaw działania i gwarancji samodzielności służyły w pierwszej fazie kształtowania koncepcji samorządu w Polsce jako źródło inspiracji i wzorów, uwydatniajacych właśnie europejski wymiar dokonywanych zmian. Później, jak pisze dalej Jeżewski, gdy ustawa samorządowa, w krótkim czasie opracowana i szybko wdrożona, z powodzeniem odegrała swą rolę, uwalniając mechanizmy lokalnego rozwoju i przedsiębiorczości z ograniczeń i inercji niedawnego centralizmu, wiedza o samorządzie zachodnioeuropejskim okazała się przydatna jako układ odniesienia do oceny i weryfikacji kształtującej się praktyki ${ }^{36}$.

${ }^{34}$ J. Korczak, op. cit., s. 179. Por. E. Wojciechowski, Samorzad terytorialny w warunkach gospodarki rynkowej, Warszawa 1997; S. Dudzik, Działalność gospodarcza samorzqdu terytorialnego. Problematyka prawna, Kraków 1998.

${ }^{35}$ Ibidem, s. 180. Por. M. Kulesza, Zasada subsydiarności jako klucz do reform ustroju administracyjnego państw Europy Środkowej $i$ Wschodniej (na przykładzie Polski), w: D. Milczarek (red.), Subsydiarność, Warszawa 1998, s. 119; J. Jeżewski (red.), Samorzad terytorialny i administracja w wybranych krajach. Gmina w państwach Europy Zachodniej, Wrocław 1999.

${ }^{36}$ J. Jeżewski, Od Redaktora, w: idem (red.), op. cit., s. 12-13. Por. H. Rot (red.), Ustrój i funkcje samorzqdu terytorialnego. Studia i szkice, Wrocław 1993; Z. Niewiadomski, Samorzqd w warunkach państwa kapitalistycznego, Warszawa 1988; M. Miemiec, Gmina w administracji publicznej Republiki Federalnej Niemiec, Wrocław 2007. 
Wykonywanie regulacji prawnomiędzynardowych, w tym unijnych, było przedmiotem zainteresowania doktryny $\mathrm{w}$ różnych obszarach związanych ze statusem i funkcjonowaniem samorządu terytorialnego w państwie.

W kontekście rozważań poświęconych integracji obszarów władzy wykonawczej z Unią Europejską Teresa Rabska uwypukla sytuację samorządu terytorialnego. Autorka pisze, że obecnie coraz wyraźniej liczy się jakość i skuteczność zarządzania sprawami publicznymi i publicznym majątkiem. Jeżeli tak się spojrzy na to zagadnienie, to opinia ta w całej rozciagłości odnosi się także do naszej krajowej administracji publicznej, której głównym nerwem jest samorząd terytorialny. Śmiem więc twierdzić - akcentuje dalej Rabska że to właśnie administracja publiczna odgrywa i będzie odgrywała decydująca rolę w procesie integracji europejskiej. Przy czym, przy panujących tendencjach centralistycznych, nie jest doceniana w tym zakresie rola administracji samorządowej. A to właśnie samorząd terytorialny będzie w pierwszej kolejności wdrażał w praktyce unijne regulacje prawne ${ }^{37}$. Podsumowując rozważania odnoszące się do administracji publicznej w świetle integracji z Unią Europejska, Rabska stwierdza, że metody działania dyktowane sa także potrzebami wewnętrznymi, wynikają wciąż z konieczności wyrównywania zaległości, które stale nad nimi ciążą. Jeżeli nie chcemy żyć w zacofaniu w stosunku do innych krajów, to działania te muszą być bezwzględnie podjęte przez aparat państwowy ${ }^{38}$.

$\mathrm{Na}$ gruncie rozważań dotyczących tworzenia prawa podatkowego przez lokalne organy władzy publicznej Leonard Etel zwraca uwagę na uwarunkowania prawnomiędzynarodowe. Autor pisze, że z formalnoprawnego punktu widzenia o tym, że rozważane organy lokalne mają kompetencje prawotwórcze w zakresie podatków, decyduja postanowienia Konstytucji RP oraz EKSL nakazujące przyznanie samorządowi prawnych form oddziaływania na podatki i opłaty lokalne. Z art. 9 ust. 3 EKSL $^{39}$ wynika, że przynajmniej część zasobów finansowych społeczności lokalnych powinna pochodzić z opłat i podatków lokalnych, których wysokość społeczności te mają prawo ustalać w zakresie określonym ustawa. Zgodnie z przywoływanym przepisem w zapatrywaniu Etela właściwe organy odpowiednich jednostek samorządu terytorialnego powinny mieć realny wpływ na wysokość podatków i opłat lokalnych, a to jest możliwe jedynie wówczas, gdy będą miały ustawowe kompetencje do tworzenia prawa podatkowego. Z tymi wymogami EKSL koresponduje zdaniem autora art. 168 Konstytucji RP, w którym jest zawarte prawo jednostek samorządu terytorialnego do ustalania wysokości podatków i opłat lokalnych w zakresie określonym w ustawie: „Ustalanie wysokości podatków [...] przez samorząd może się odbywać, co nie budzi wątpliwości, jedynie w drodze uchwalania aktów normatywnych”. Jeżeli zatem Konstytucja RP i wiążąca umowa międzynarodowa, której Polska jest strona, nakazują wyposażenie samorządu te-

${ }^{37}$ T. Rabska, Administracja publiczna..., s. 3.

${ }^{38}$ Ibidem, s. 11.

${ }^{39}$ L. Etel, Tworzenie prawa podatkowego przez władzę lokalna, w: W. Miemiec (red.), Stanowienie $i$ stosowanie prawa podatkowego. Ksiega Jubileuszowa Profesora Ryszarda Mastalskiego, Wrocław 2009, s. 144. 
rytorialnego $\mathrm{w}$ omawiane prerogatywy do nakładania danin publicznych, to ustawodawca „Zwykły” musi to w ustawach zrealizować ${ }^{40}$.

Z kolei badając zagadnienie polityki podatkowej oraz działalności prawotwórczej - podstawowej jednostki samorządu terytorialnego - Krystyna Sawicka akcentuje, że jeżeli instrumenty polityki podatkowej są kierowane do podatnika, który jest przedsiębiorca, a jego przysporzenie finansowe $\mathrm{z}$ tego tytułu jest związane z prowadzoną przez niego działalnościa gospodarczą i jednocześnie wypełnia cechy wsparcia $\mathrm{z}$ d. art. 87 ust. $1 \mathrm{TWE}^{41}$, to organy gminy są zobowiązane równolegle $\mathrm{z}$ prawem podatkowym stosować unijne (wspólnotowe) i krajowe prawo pomocy publicznej. W takiej sytuacji uchwały podatkowe muszą zawierać rozwiąania zgodne z przepisami polskiego prawa podatkowego, a zarazem adekwatne do przepisów regulujących warunki i tryb udzielania pomocy publicznej ${ }^{42}$. Działanie prawa pomocy publicznej determinuje dobór rozwiązań merytorycznych przyjętych w uchwałach podatkowych gmin. Podstawa prawna stosowania pomocy publicznej sa w przekonaniu autorki przepisy prawa unijnego, uzupełnione przepisami prawa krajowego, które w zasadzie ograniczaja się do regulacji trybu udzielania pomocy i jej monitorowania. Natomiast właściwe normy prawne konstruujace instrumenty udzielania pomocy publicznej, choć musza być stosowane z respektowaniem wymogów prawa pomocy publicznej, nie należa jednak do tego prawa. Sawicka jest zdania, że instrumenty te (będące formami pomocy publicznej) maja swoje źródło w ustawodawstwie szczególnym, w tym w prawie podatkowym. W konsekwencji rozważany mechanizm prawny udzielania pomocy publicznej opiera się na jednoczesnym działaniu wydzielonych trzech segmentów norm prawnych $^{43}$.

Ogląd praktyki funkcjonowania samorządu terytorialnego w Polsce $\mathrm{w}$ aspekcie omawianych uwarunkowań prawnomiędzynarodowych prowadzi do istotnych konstatacji w zakresie niniejszych rozważań. Dokonane przez Michała Kuleszę badania aktywności samorządu terytorialnego pokazuja, że polskie rozwiązania, mimo zupełnie wystarczających podstaw konstytucyjnych i ustawowych, w praktyce zmierzaja w kierunku ograniczenia samodzielności podstawowej jednostki samorządu terytorialnego. Autor zawraca uwagę, że wbrew postanowieniu art. 3 ust. 1 EKSL, że „Samorząd lokalny oznacza p r awo i zdolność społeczności lokalnych, w granicach określonych prawem, do kierowania i zarządzania zasadniczą częścią spraw publicznych na ich własną odpowiedzialność i w interesie ich mieszkańców", w przedstawionym ujęciu radykalnemu zawężeniu ulega „prawo”, a w ślad za tym - „zdolność” społeczności lokalnych do zarządzania swoimi sprawami. Dzieje się to poprzez wypieranie ogólnych podstaw prawnych i zastępowanie ich rozwiązaniami szczegółowymi i kazuistycznymi, również na tych obszarach, gdzie nie przewiduje się kompetencji władczych. Rozwiązania szczegółowe - w opinii Kuleszy - które

${ }^{40}$ Ibidem, s. 145 .

41 Traktat ustanawiajacy Wspólnotę Europejską (tekst jedn. Dz. Urz. C 325 z 24 grudnia 2002 r., s. 33-184; dalej jako: TWE, WE etc.).

${ }^{42}$ K. Sawicka, Polityka podatkowa gminy, w: W. Miemiec (red.), op. cit., s. 395.

43 Ibidem, s. 396. 
przy działalności organizatorskiej zazwyczaj są niedoskonałe i najczęściej spóźnione, służą wiązaniu samorządu terytorialnego, by zawsze (również w sferze niewładczej) działał „w ramach i na podstawie prawa”, a nie tylko „w ramach prawa”. Autor trafnie uwypukla, że EKSL głosi „w granicach określonych prawem”, a nie „na podstawie ustawy”. W ten sposób zdaniem Kuleszy następuje zanegowanie zasadniczych mechanizmów i sensu samodzielności komunalnej i w konsekwencji upodobnienie samorządu terytorialnego do hierarchicznie podporządkowanych organów administracji rządowej, które muszą działać nie tylko „w ramach”, lecz zawsze „na podstawie ustawy”. Jest chyba oczywiste pisze dalej autor, w kategoriach „zaspokajania potrzeb wspólnoty”, że takie podejście jest znacznie mniej skuteczne, aniżeli podejście otwarte, pozwalające samodzielnie określać cele (korzyści) publiczne i swobodnie dobierać środki do celów, z uwzględnieniem - nikt tego nie kwestionuje - różnych ograniczeń prawnych. Neguje się tym samym samodzielność gminy w ustalaniu kierunków działania i podejmowanych zadań, mimo że podstawowa jednostka samorządu terytorialnego widzi w tym korzyść (dla interesu publicznego), żaden zaś wyraźny przepis nie stoi temu na przeszkodzie i mimo wyraźnych podstaw do podejmowania takich działań zawartych w odpowiednich aktach powszechnie obowiąujących. Dla porządku trzeba jednak wskazać, jak pisze dalej autor, że istnieje też i odmienna praktyka w omawianym zakresie ${ }^{44}$.

\section{WNIOSKI}

Przywołane przykładowo opinie naukowe odnoszace się do prawnomiędzynarodowych uwarunkowań samorządu terytorialnego ze zrozumiałych względów nie wyczerpuja pola badawczego. Tytułem przykładu wskażmy, iż od połowy lat siedemdziesiątych ubiegłego wieku, o czym wspomina Konrad Nowacki, były organizowane kolokwia administratywistów - co dwa lata na przemian w Niemczech i w Polsce, skupiajace znawców prawa publicznego obu krajów. Koncepcję wspólnych spotkań naukowych zaproponowali na konferencji we Wrocławiu w 1972 r. profesorowie Jan Jendrośka (Wrocław), Franz Mayer (Ratyzbona) i Jerzy Starościak (Warszawa). W trakcie owych spotkań podejmowano zawsze podstawowe tematy prawa administracyjnego, w tym także zawierające treści ujęte w tytule opracowania ${ }^{45}$.

${ }^{44} \mathrm{M}$. Kulesza, O tym, ile jest decentralizacji w centralizacji, a także o osobliwych nawykach uczonych administratywistów, w: J. Supernat (red.), op. cit., s. 410-411. Por.: T. Rabska, Zasada gospodarki rynkowej a samodzielność jednostek samorzqdu terytorialnego, w: A. Gomułowicz, J. Małecki (red.), Ex iniuria non oritur ius. Księga ku czci Profesora Wojciech Eqczkowskiego, Poznań 2003, s. 91; L. Kieres, Wolność gospodarcza w dziatalności jednostek samorzqdu terytorialnego, w: Instytucje wspótczesnego prawa administracyjnego, Kraków 2001, s. 323; A. Agopszowicz, M. Ciepiela, Wolność gospodarcza jednostek samorzqdu terytorialnego jako kwestia otwarta, w: L. Ogiegło, W. Popiołek, M. Szponar (red.), Rozprawy prawnicze. Księga pamiatkowa profesora Maksymiliana Pazdana, Kraków 2005, s. 779.

${ }^{45}$ K. Nowacki, Wprowadzenie, w: idem (red.), Kontrola działania administracji, Wrocław 2010, s. 15. 
Niniejsze rozważania dają podstawę do stwierdzenia, że prawnomiędzynarodowe uwarunkowania samorządu terytorialnego sa od dawna obiektem zainteresowania doktryny, są również materią złożoną którą należy ujmować w szerszym wymiarze zachodzacych zmian w odniesieniu do państwa polskiego. Początku tego zjawiska należy upatrywać zwłaszcza w przemianach społecznych, politycznych i gospodarczych prowadzących do odejścia od formacji państwa socjalistycznego.

Prawnomiędzynarodowe uwarunkowania samorządu terytorialnego zachodziły głównie pod wpływem porządku prawnego i działalności Rady Europy i wkomponowują się w zjawisko natury ogólniejszej. Otwarcie Konstytucji RP na prawo międzynarodowe i prawo Unii Europejskiej, a w konsekwencji wieloskładnikowy charakter prawa polskiego - jak podkreślają Stanisław Biernat i Monika Niedźwiedź - wywiera istotny wpływ na podstawy prawne funkcjonowania polskiej administracji publicznej, w tym samorządu terytorialnego. Podstawami prawnymi działania polskiej władzy wykonawczej (administracji publicznej) sa nie tylko normy stanowione przez polskie organy prawotwórcze, ale także normy prawa międzynarodowego i normy prawa unijnego ${ }^{46}$. Zwiększajacy się udział prawa międzynarodowego, w tym prawa unijnego i jego praktyki w formowaniu statusu jurydycznego samorządu terytorialnego w państwie wpisuje się w nurt ogólniejszy, który obejmuje wzrastający wpływ prawa międzynarodowego (prawa narodów) na kształtowanie się systemu prawa administracyjnego. Jak zauważył Tadeusz Bigo: „W ostatnich czasach zaznacza się duży przyrost norm prawa narodów, co przyczynia się do rozwoju prawa administracyjnego" 47 .

prof. dr hab. Karol Kiczka

Uniwersytet Wroctawski

karolkiczka@prawo.uni.wroc.pl

\title{
INTERNATIONAL LEGAL BACKGROUND OF SELF-GOVERNANCE
}

\author{
Sum mary
}

The article tackles selected issues regarding the significance of international law and other regulations, including the provisions of the EU law, on the juridicial status of self-governance in Poland. The researched material and its analysis indicate that international legislation and the legislative achievements of the Council of Europe in particular, have been taken into account in the process of the restitution of self-government structures in Poland.

${ }^{46}$ S. Biernat, M. Niedźwiedź, Znaczenie prawa międzynarodowego $i$ unijnego dla prawa administracyjnego $i$ administracji publicznej $w$ świetle Konstytucji RP, w: R. Hauser, Z. Niewiadomski, A. Wróbel (red.), op. cit., s. 106. Por. K. Kiczka, Krajowy organ administracji publicznej w prawie unijnym, Wrocław 2013, s. 345-354.

${ }^{47}$ T. Bigo, Administracja, cz. 1: Zarys nauki administracji i polskiego prawa administracyjnego, Lwów 1937, s. 32-33. 